\title{
Bathya brevicarpus gen. et sp. nov. (Amphipoda: Senticaudata: Calliopiidae), from hydrothermal vents, Okinawa Trough, North-west Pacific
}

\author{
Yan-Rong WANG ${ }^{1}$, Chao-Dong ZHU ${ }^{2}$, Zhong-Li SHA ${ }^{3, *} \&$ Xian-Qiu REN ${ }^{4}$ \\ ${ }^{1,2}$ Key Laboratory of Zoological Systematics and Evolution, Institute of Zoology, \\ Chinese Academy of Sciences, Beijing 100101, China. \\ ${ }^{1,3,4}$ Institute of Oceanology, Chinese Academy of Sciences, Qingdao 266071, China. \\ ${ }^{3}$ Laboratory for Marine Biology and Biotechnology, Qingdao National Laboratory \\ for Marine Science and Technology, Qingdao, China. \\ ${ }^{3}$ Center for Ocean Mega-Science, Chinese Academy of Sciences, Qingdao 266071, China. \\ ${ }^{1,2,3}$ College of Biological Sciences, University of Chinese Academy of Sciences, \\ Beijing 100049, China. \\ "Corresponding author: shazl@qdio.ac.cn \\ 1Email: wangyr@qdio.ac.cn \\ 2Email: zhucd@ioz.ac.cn \\ [4Email: 1278593370@qq.com

\footnotetext{
${ }^{1}$ urn:lsid:zoobank.org:author:30EE7948-0A00-431B-8A67-B52F531FEC66

${ }^{2}$ urn:lsid:zoobank.org:author:0DDF9891-C900-47A5-9E44-978388C41181

${ }^{3}$ urn:lsid:zoobank.org:author:ECB423CA-544C-4765-9F40-484DB8BA1001
} \\ ${ }^{4}$ urn:Isid:zoobank.org:author:6AA3884A-5BE7-4C2D-A597-9C270BC37A7D
}

\begin{abstract}
One individual referable to Calliopiidae G.O. Sars, 1893 was collected from a chemically reduced habitat, the hydrothermal vent systems in Okinawa Trough, and was identified as a new genus and species belonging to this family after a morphological examination. A formal description of this new species and a discussion of the relationship of the new genus within Calliopiidae are presented.
\end{abstract}

Keywords. Taxonomy, morphology, Calliopiidae, new genus, deep sea.

Wang Y.-R., Zhu C.-D., Sha, Z.-L. \& Ren X.-Q. 2020. Bathya brevicarpus gen. et sp. nov. (Amphipoda: Senticaudata: Calliopiidae), from hydrothermal vents, Okinawa Trough, North-west Pacific. European Journal of Taxonomy 693: 1-12. https://doi.org/10.5852/ejt.2020.693

\section{Introduction}

The calliopiids have been placed in the Eusiroidea Stebbing, 1888 (e.g., Bousfield \& Hendrycks 1995, 1997; De Broyer et al. 2007). A phylogenetic study based on morphology by Lowry \& Myers (2013) showed that the Calliopiidae G.O. Sars, 1893 sit in the Hadziidira S. Karaman, 1943 and have a close relationship with Pontogeneiidae Stebbing, 1906. This family currently contains 27 genera and more 
than 100 species, most of which are described from arctic and subarctic regions (e.g., Barnard \& Karaman 1991; Ren \& Huang 1991; Weisshappel 2001; d'Udekem d'Acoz 2007, 2010, 2012). The calliopiids reported from vent fields are represented by two species: Bouvierella curtirama BellanSantini \& Thurston, 1996 collected at a depth of $1636 \mathrm{~m}$ from the mid-Atlantic Ridge and Leptamphopus fragilis Larsen \& Krapp-Schickel, 2007 collected at a depth of 2656 m near Wuzza Bare Mount, northeast Pacific (Bellan-Santini \& Thurston 1996; Larsen \& Krapp-Schickel 2007). The Chinese research vessel "KEXUE", using the remote operated vehicle (ROV) "FAXIAN" to survey the biodiversity of hydrothermal vents in Okinawa Trough, collected one unusual specimen referable to Calliopiidae. A morphological examination shows that this individual is a new calliopiid. However, the new species does not belong to any of the described genera within this family based on the combination of the following morphological characters: a small rostrum; the absence of the antennae calceoli; the article 3 of antenna 1 not produced apicoventrally; the inner plate of maxilla 1 bearing only one apical seta; the gnathopod 2 not linear or greatly elongate and the carpus of the gnathopods 1-2 much shorter than the propodus; pereopod 5 slightly longer than pereopod 7; epimeron 3 smooth; the outer ramus of uropod 3 half-length of the inner ramus; the entire telson, longer than broad. Hence, a new genus, Bathya gen. nov., is erected to accomodate this new species herein. A key to all genera of Calliopiidae is also presented.

\section{Material and methods}

The present material was collected by ROV "FAXIAN", during expeditions to the Okinawa Trough hydrothermal vents by the Institute of Oceanology, Chinese Academy of Sciences (IOCAS) in April 2014. The type specimen examined is deposited in the Marine Biological Museum, Chinese Academy of Sciences (MBMCAS), Qingdao, China, and preserved in 75\% ethanol. It was examined and dissected under a dissecting microscope (ZEISS Discovery V20). Line drawings were made with a tablet (Wacom Intuos Pro PTH-851) and Adobe Photoshop (ver. CS6). The length measurements are made along the outline of the animals, beginning from the anterior margin of head to the end of the telson.

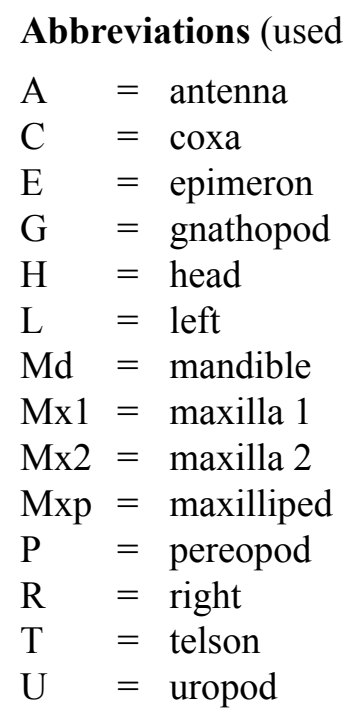


WANG Y.-R. et al., A new genus and species of Calliopiidae (Amphipoda) from Okinawa Trough

\title{
Results
}

\author{
Order Amphipoda Latreille, 1816 \\ Suborder Senticaudata Lowry \& Myers, 2013 \\ Superfamily Calliopioidea G.O. Sars, 1893 \\ Family Calliopiidae G.O. Sars, 1893 \\ Genus Bathya gen. nov. \\ urn:1sid:zoobank.org:act:AA9C504C-CE7E-426A-A988-27098BD64D25
}

Type species
Bathya brevicarpus gen. et sp. nov.

Diagnosis

Antennae calceoli absent. Antenna 1 longer than antenna 2; accessory flagellum absent. Mandible molar triturative, columnar; palp 3-articulate, extremely elongated, article 3 longer than article 2. Maxilla 1 inner plate bearing one apical seta; palp article 1 shorter than article 2. Maxilla 2 inner plate without oblique setal row. Maxilliped outer plate not reaching end margin of palp article 2. Gnathopod 1 similar in shape to gnathopod 2, slightly smaller than gnathopod 2; subchelate; carpus much shorter than propodus; with posterior lobe. Coxae 5-6 bilobate, posterior lobe larger than anterior lobe; coxa 7 rounded. Pereopod 5 slightly longer than pereopod 7; anterior margin of propodus with bifid robust setae; dactylus simple, with small nail. Epimerons 2-3 posterior margin smooth, posteroventral corner of epimeron 2 subacute. Uropods 1-2 inner ramus longer than outer ramus, both inner and outer ramus with marginal robust setae. Uropod 3 inner ramus about twice longer than outer ramus, both inner and outer ramus with marginal robust setae, without simple or plumose setae. Telson entire, linguiform, longer than broad.

\section{Etymology}

The generic name Bathya refers to the type species designated herein that was collected from bathyal waters.

\section{Distribution}

North-west Pacific, Okinawa Trough, the hydrothermal vents at a depth of $996.9 \mathrm{~m}$.

\section{Remarks}

Actually, it is a little questionable that Bathya gen. nov. is placed under the Calliopiidae G.O. Sars, 1893 for having the pereopod 5 longer than pereopod 7. The phylogenetic study by Lowry \& Myers (2013) based on morphology analyzed showed that the Calliopiidae and Pontogeneiidae Stebbing, 1906 cluster together and form a clade with Hornelliidae d'Udekem d'Acoz, 2010 and Cheirocratidae d'Udekem d'Acoz, 2010. The new genus is not listed under Cheirocratidae or Hornelliidae, which are also not having antennae calceoli, for having the following characteristics: the inner plate of maxilla 1 only bearing apical seta, maxilla 2 without oblique setal row, the rami of uropod 3 unequal in length, and the entire telson. The new genus is not suited to be placed in Pontogeneiidae for the propodus of gnathopod 2 having robust setae along the palmar margin. Moreover, Sanchoidae Lowry, 2006, which are known as endemic to Australia and associated with sponges (Lowry \& Barnard 2001), have been listed under the Calliopiidae. However, the present genus cannot be incorporated in this family for the lack of a nonrecessed head and a dorsoventrally flattened urosome (Lowry 2006). Hence, it is more reasonable that this new genus is to be placed under Calliopiidae with an emendation of the diagnosis of this family. 
Besides having the pereopod 5 longer than pereopod 7, Bathya gen. nov. can be distinguished its congeners of the Calliopiidae by having the combination of the following characters: eyes present but not well pigmented; antenna 1 longer than antenna 2; the absence of an accessory flagellum; the inner plate of maxilla 1 only bearing one apical seta; maxilla 2 without oblique setal row; gnathopod 1 similar in shape and size to gnathopod 2; pleonites 1-3 without dorsal carinae; the rami of uropod 3 unequal in length; the entire telson.

Bathya brevicarpus gen. et sp. nov. urn:Isid:zoobank.org:act:2A8520B1-C0C6-4BAB-9C8D-A7DFB57B111D

Figs $1-2$

\section{Diagnosis}

As for the genus.

\section{Etymology}

The new species name contains the Latin 'brev' (= short), referring to the carpus of the gnathopods 1 and 2 being shorter than the propodus.

\section{Material examined}

\section{Holotype}

NORTH-WEST PACIFIC • $\widehat{\text { O }}, 5.6 \mathrm{~mm}$, dissected; Okinawa Trough; depth 996.9 m; 17 Apr. 2014; RY0108, ROV-4; MBM 286556.

\section{Description}

Body. Dorsally smooth.

HEAD. Nearly subequal in length to pereonites 1 and 2 combined, rostrum small, anterior lobe rounded, lower margin with large and acute projecting tooth anterodistally; eyes present, but not pigmented, hardly visible in ethanol material.

ANTENNA. Antenna 1 longer than antenna 2; peduncular article 1 wider and longer than article 2; article 2 less than twice longer than article 3; article 3 not produced apicoventrally; primary flagellum 23-articulate, few very thin and short setae scattered along flagellum; accessory flagellum absent. Antenna 2 slender than antenna 1, peduncular article 5 distinctly longer than article 4; flagellum longer than peduncle, 28-articulate.

MOUTH PARTS. Upper lip and lower lip broken. Mandible symmetrical, with incisor dentate, bearing 7 teeth; lacinia mobilis dentate, with 8 teeth; with 12 accessory spines; molar well developed, columnar, triturative; palp elongate, slender, 3 -articulate, article 3 longer than article 2, ventral face bearing short stout setae. Maxilla 1 with inner plate bearing one apical stout seta; palp 2-articulate, article 2 longer than article 1, bearing 6 small robust and three long simple setae. Maxilla 2 inner plate slightly narrower than outer, only bearing sparse slender subapical marginal setae, without oblique row of slender setae.

Gnathopods. Coxae 1-4 longer than broad, coxa 4 broader than coxae 1-3. Gnathopod 1 subchelate, slightly smaller than gnathopod 2; coxa weakly produced anteroventrally; merus subrectangular, bearing row of slender setae along distal margin; carpus shorter than propodus, cup-shaped, with dense long slender setae on posterior margin; propodus suboval, palm acute, posterior margin with robust and short simple setae; dactylus evenly tapering, with acute tip. Gnathopod 2 similar in shape to ganthopod 1; coxa subrectangular, subequal in length to coxa 1, anterior margin slightly convex; carpus distinctly 


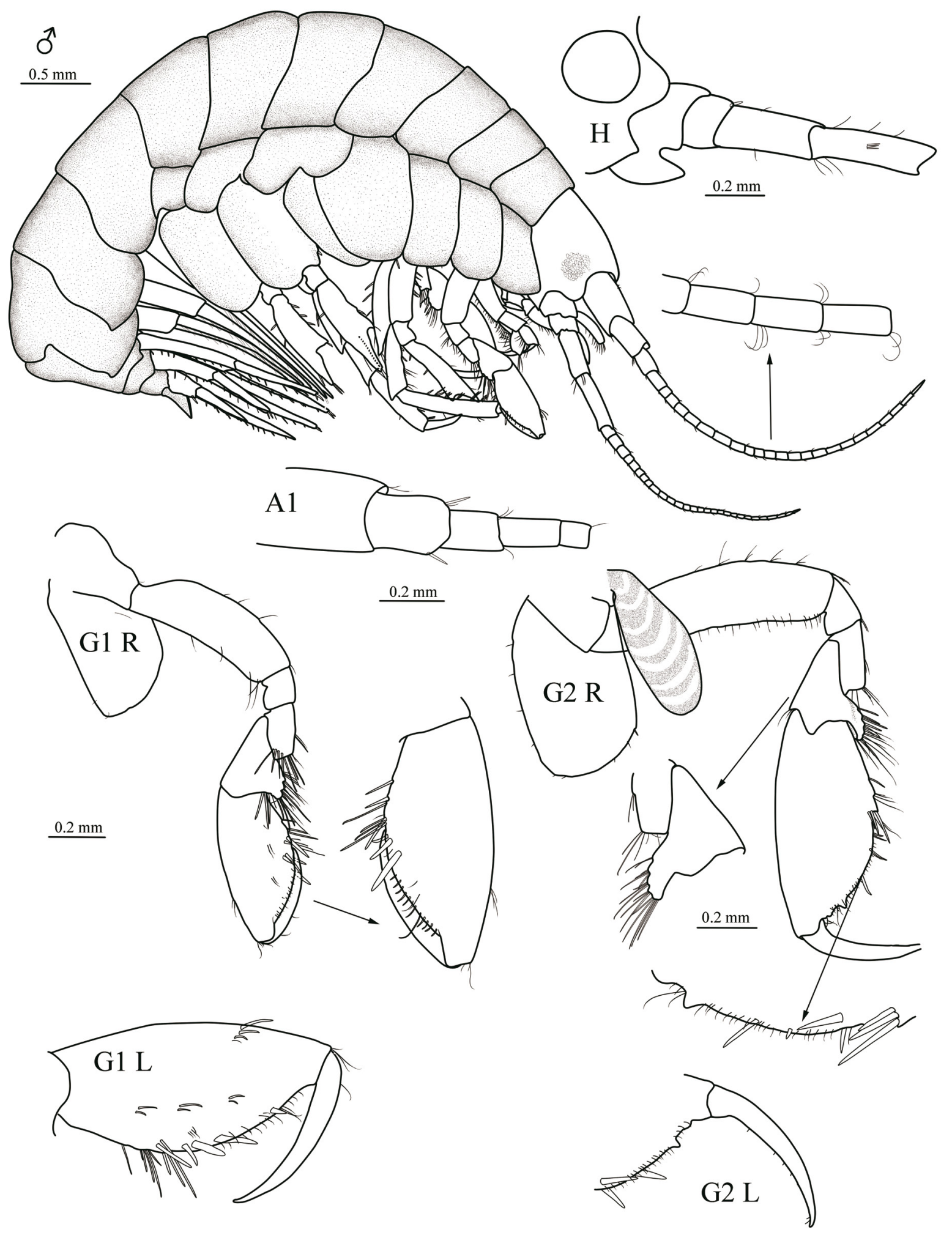

Fig. 1. Bathya brevicarpus gen. et sp. nov., holotype, $ð$ (MBM 286556). 

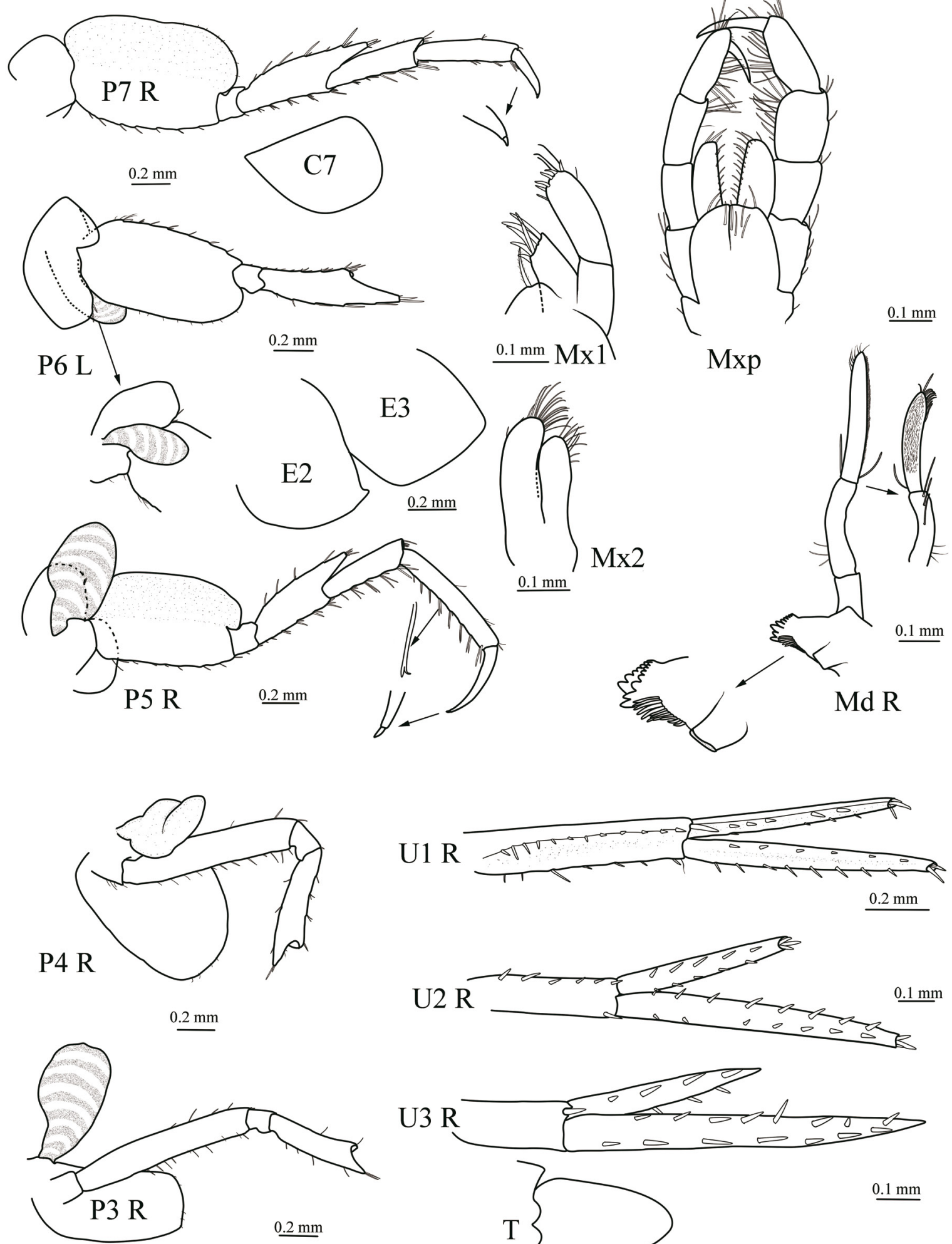

U3 R

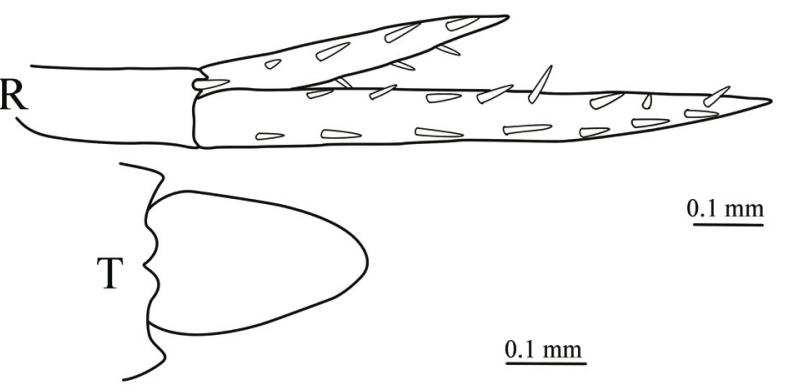

Fig. 2. Bathya brevicarpus gen. et sp. nov., holotype, ô (MBM 286556). 
WANG Y.-R. et al., A new genus and species of Calliopiidae (Amphipoda) from Okinawa Trough

shorter than propodus, weakly lobed; propodus with tooth-like protruded sub-distally, bearing short simple and robust setae along posterior margin; dactylus with acute tip, evenly tapering.

Pereopods. Pereopod 3 (distal three articles broken in holotype) slender, merus bearing large produced lobe anterodistally. Pereopod 4 similar to pereopod 3, but coxa much broader. Pereopod 5 slightly longer than pereopod 7, coxa bilobate, anterior lobe smaller than posterior lobe; merus broader than distal three articles, with posterodistal strongly produced as lobe, anterior margin with 4+ groups of 2-3 robust setae; propodus 1.4 times longer than carpus, anterior margin bearing 8 groups of $2-3$ bifid robust setae; dactylus slender, with acute tip, evenly tapering, 0.7 length of propodus, with small nail. Pereopod 6 (distal three articles broken in holotype) gill smaller than that of pereopod 5; coxa bilobate, anterior lobe much smaller than posterior lobe; basis slight longer than that of pereopod 5. Pereopod 7 coxa unilobate, rounded; basis broader than that of pereopods 5 and 6 , anterior margin bearing robust setae; propodus subequal in length to carpus; dactylus half-length of propodus, with small acute nail.

GiLLs. Present on coxae 2-6, small, not pleated.

EPIMERAL PLATES 1 AND 3. Without tooth on posterior margin, postero-corner of epimeral 2 being subacute.

UROPODS. Uropod 1 overreaching distal end of uropod 2, without interramal spur; peduncle shorter than rami, with 19 marginal and one large distal robust setae; outer ramus shorter than inner ramus, but subequal in broad to inner, with 9 marginal and three distal robust setae; inner ramus with 14 marginal and 3 distal robust setae. Uropod 2 peduncle distinctly shorter than rami, with 5 marginal and two distal robust setae; outer ramus 0.6 times shorter than inner ramus, with 10 marginal and three distal robust setae; inner ramus with 15 marginal and three distal robust setae. Uropod 3 shorter than uropod 2, peduncle shorter than rami, with one robust seta distally; outer ramus 0.55 times shorter than inner ramus, with 7 marginal robust setae; inner ramus with 15 marginal robust setae.

Telson. Entire, longer than broad (length 1.7 times as long as width at base), distal margin convex.

\section{Discussion}

The calliopiids are cosmopolitan (Barnard 1964; Bousfield \& Hendrycks 1997; Lowry \& Myers 2012), and have been reported from various environments including fresh water, bipolar, shallow and deep waters and hydrothermal vents (e.g., Barnard \& Karaman 1991; Bellan-Santini \& Thurston 1996; KrappSchickel \& Sorbe 2006; d'Udekem d'Acoz 2007; Lowry \& Myers 2012; Ringvold \& Tandberg 2014). For example, species of the most species-rich genus of Calliopiidae, Apherusa Walker, 1891, are mostly recorded from the neritic environment (Barnard \& Karaman 1991; Krapp-Schickel \& Sorbe 2006) and 13 of 17 known species of Oradarea Walker, 1903 are found in the Antarctic and sub-Antarctic islands (Alonso 2012). Two calliopiids, Bouvierella curtirama Bellan-Santini \& Thurston, 1996 and Leptamphopus fragilis Larsen \& Krapp-Schickel, 2007, have been reported from vent fields. However, the present new species belongs to neither Bouvierella Chevreux, 1900 nor Leptamphopus G.O. Sars, 1893 (see Table 1). This is the third calliopiid from a hydrothermal vent habitat. As the new species cannot be assigned to any genus of Calliopiidae, a new genus is erected herein. Additionally, a key to all genera of the Calliopiidae is presented below.

Moreover, the morphological differences between several genera of Calliopiidae, such as Halirages Boeck, 1871, Haliragoides G.O. Sars, 1893 and Apherusa, are blurred (Ringvold \& Tandberg 2014). The phylogenetic analyses based on a comparison of $18 \mathrm{~S}$ and $28 \mathrm{~S}$ rDNA sequences by Verheye et al. (2016) shows that the Calliopiidae are not monophyletic. Hence, the entire calliopiid family is in need of revision. 
Table 1. Synoptic table comparing Bathya brevicarpus gen. et sp. nov. and congeneric calliopiids reported from vent fields on the basis of literature data.

\begin{tabular}{lllll}
\hline Species & Accessory flagellum & Eyes & Gnathopod 2 & Telson \\
\hline Bathya brevicarpus & absent & present & not linear & entire \\
Bouvierella curtirama & present & absent & linear & truncate \\
Leptamphopus fragilis & present & absent & linear & cleft \\
\hline
\end{tabular}

\section{Identification key to genera of the Calliopiidae}

Key based on original or amended descriptions of genera and adapted from previous keys given by Barnard (1964), Barnard \& Karaman (1991) and Bousfield \& Hendrycks (1997). All genera included in this key are according to Lowry \& Myers (2013) and WoRMS (2020).

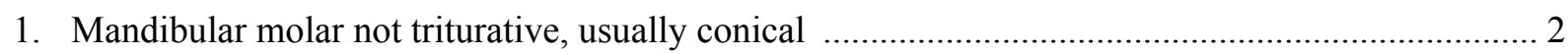

- Mandibular molar triturative, columnar, rather conical ............................................................ 3

2. Carpus of gnathopods $1-2$ shorter than propodus, weakly lobed; antenna 2 elongate

Harpinioides Stebbing, 1888

- Carpus of gnathopods 1-2 as long as propodus, unlobed; antenna 1 elongate

Calliopiurus Bushueva, 1986

3. Inner plate of maxilla 2 much broader than outer plate

Pontogeneoides Nicholls, 1938

- Inner plate of maxilla 2 not much broader than outer plate

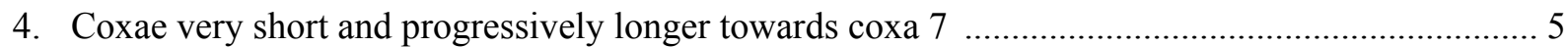

- Coxae not as greatly shortened and not progressively lengthened towards coxa 7 ......................... 6

5. Carpus and propodus of pereopods 6-7 extremely elongate (planktonic); body carinate; coxa 1 not or scarcely produced anteriorly

Stenopleuroides Birstein \& M. Vinogradov, 1964

- Carpus and propodus of pereopods 6-7 not extremely elongate; body smooth; coxa 1 produced anteriorly

Stenopleura Stebbing, 1888

6. Palp of maxilla 1 reduced, not exceeding apex of outer plate, article 1 longer than article 2

Laothoes Boeck, 1871

- Palp of maxilla 1 ordinary, article 1 shorter than article 2

7. Rami of uropods $1-2$ without marginal robust setae, only with distal robust setae

Calliopiella Schellenberg, 1925

- Rami of uropods 1-2 with both marginal and distal robust setae

8. Gnathopods 2 very slender, linear, carpus very slender and elongate, unlobed, propodus generally elongate and linear (except in Amphithopsis)

- Gnathopod 2 not very slender nor linear nor greatly elongate (propodus not especially elongate) ....

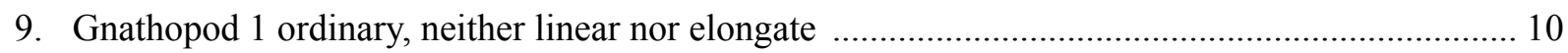

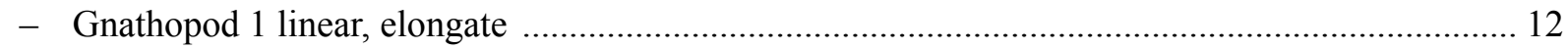


WANG Y.-R. et al., A new genus and species of Calliopiidae (Amphipoda) from Okinawa Trough

10. Propodus of gnathopod 2 not linear; dactylus of pereopods 3-7 serrated

Amphithopsis Boeck, 1861

- Propodus of gnathopod 2 linear; dactylus of pereopod 3-7 not serrated 11

11. Accessory flagellum absent; lower lip with inner lobe absent

Bouvierella Chevreux, 1900

- Accessory flagellum present; lower lip with inner lobe present Oradarea Walker, 1903

12. Dactylus of pereopods 3-7 with one or more superior robust setae Cleippides Boeck, 1871

- Dactylus of pereopods 3-7 without superior robust setae 13

13. Carpus of gnathopods $1-2$ much longer than propodus 16

- Carpus of gnathopods 1-2 scarcely longer and usually shorter than propodus 14

14. Gnathopod 2 much longer than gnathopod 1, carpus and propodus extremely slender like that of pereopod 3-7 Leptamphopus G.O. Sars, 1893

- Gnathopod 2 as long as or slightly longer than ganthopod 1, carpus and propodus normal 15

15. Telson entire, linguiform Membrilopus Barnard \& Karaman, 1987

- Telson with shallow apical notch on distal margin Frigora Ren in Ren \& Huang, 1991

16. Antennae calceolate; antenna 1, peduncular article 3 with posterodistal process; uropod3, rami margin only with simple setae Halirages Boeck, 1871

- Antennae usually lacking calceoli; antenna 1, peduncular article 3 unmodified; uropod 3, margins with robust setae and inner marginal setae only

17. Propodus of gnathopods expanded; pereopods $5-7$ elongated

Haliragoides G.O. Sars, 1893

- Propodus of gnathopods not expanded; pereopods 5-7 normal, not extremely elongated

Apherusa Walker, 1891

18. Peduncular article 3 of antenna 1 produced apicoventrally

- Peduncular article 3 of antenna 1 not or weakly produced apicoventrally 21

19. Carpus on either of gnathopods $1-2$ much shorter than propodus 20

- Carpus on either of gnathopods 1-2 scarcely shorter than or longer than propodus

Lopyastis Thurston, 1974

20. Carpus of gnathopods not lobate

Tylosapis Thurston, 1974

- Carpus of gnathopods strongly lobate Calliopius Lilljeborg, 1865

21. Epimeron 3 serrate 22

- Epimeron 3 smooth

22. Accessory flagellum well developed, $3+$ articulate Weygrechita Stuxberg, 1880

- Accessory flagellum scale-like Oligochinus Barnard, 1969

23. Rostrum small

- Rostrum large

24. Accessory flagellum absent

- Accessory flagellum 1-articulate, scale-like

Paracalliopiella Tzvetkova \& Kudrjaschov, 1975

25. Gnathopod 1 larger in size than gnathopod 2 Whangarusa Barnard \& Karaman, 1987

- Gnathopod 1 similar in size to gnathopod 2 
26. Carpus of gnathopods $1-2$ much shorter than propodus; outer ramus of uropod $3 \frac{1}{2}$ length of inner ramus; telson longer than broad, entire

- Carpus of gnathopods 1-2 subequal to propodus; rami of uropod 3 subequal in length; telson broader than long, emarginated Lutriwita Lowry \& Myers, 2012 (fresh water)

27. Dactylus of pereopods 3-7 bifid Manerogeneia Barnard \& Karaman, 1987

- Dactylus of pereopods 3-7 pectinate Metaleptamphopus Chevreux, 1911

\section{Acknowledgments}

Many thanks to Ed A. Hendrycks from the Department of Research and Collections, Canadian Museum of Nature for offering some papers, which were crucial during the identification process of the new species. This work was funded by the National Key R\&D Program of China (2018YFC0310702; 2018YFC0310802), the Key Research Program of Frontier Sciences, Chinese Academy of Sciences (QYZDB-SSWDQC036), the Strategic Priority Research Program of the Chinese Academy of Sciences (XDA22050302) and the National Natural Science Foundation of China (31625024).

\section{References}

Alonso G.M. 2012. Amphipod crustaceans (Corophiidea and Gammaridea) associated with holdfasts of Macrocystis pyrifera from the Beagle Channel (Argentina) and additional records from the Southwestern Atlantic. Journal of Natural History 46 (29-30): 1799-1894.

https://doi.org/10.1080/00222933.2012.692825

Barnard J.L. 1964. Revision of some families, genera and species of Gammaridean Amphipoda. Crustaceana 7 (1): 49-74. https://doi.org/10.1163/156854064X00263

Barnard J.L. \& Karaman G.S. 1991. The families and genera of marine gammaridean Amphipoda (except marine gammaroids). Records of the Australian Museum Supplement 13 (1 \& 2): 1-866.

Part 1: https://doi.org/10.3853/j.0812-7387.13.1991.91

Part 2: https://doi.org/10.3853/j.0812-7387.13.1991.367

Bellan-Santini D. \& Thurston M.H. 1996. Amphipoda of the hydrothermal vents along the mid-Atlantic Ridge. Journal of Natural History 30: 685-702. https://doi.org/10.1080/00222939600770381

Bousfield E.L. \& Hendrycks E.A. 1995. The amphipod superfamily Eusiroidea in the North American pacific region. I. Family Eusiridae: systematics and distributional ecology. Amphipacifica 1: 3-59.

Bousfield E.L. \& Hendrycks E.A. 1997. The amphipod superfamily Eusiroidea in the North American Pacific Region. II. Family Calliopiidae. Systematics and distributional ecology. Amphipacifica 2 (3): $3-66$.

De Broyer C., Lowry J.K., Jażdżewski K. \& Robert H. 2007. Synopsis of the Amphipoda of the Southern Ocean. Part 1. Catalogue of the gammaridean and corophiidean Amphipoda (Crustacea) of the Southern Ocean with distribution and ecological data. Bulletin de l'Institut royal des Sciences naturelles de Belgique 77 (Suppl. 1): 1-325.

d'Udekem d'Acoz C. 2007. The genera Haliragoides and Neohela in the North Atlantic, with the description of two new deepwater species from Norway and Svalbard (Crustacea: Amphipoda). Cahiers de Biologie marine 48 (1): 17-35.

d'Udekem d'Acoz C. 2010. Contribution to the knowledge of European Liljeborgiidae (Crustacea, Amphipoda), with considerations on the family and its affinities. Bulletin de l'Institut royal des Sciences naturelles de Belgique, Biologie 80: 127-259. 
WANG Y.-R. et al., A new genus and species of Calliopiidae (Amphipoda) from Okinawa Trough

d'Udekem d'Acoz C. 2012. On the genus Halirages (Crustacea, Amphipoda), with the description of two new species from Scandinavia and Arctic Europe. European Journal of Taxonomy 7: 1-32. https://doi.org/10.5852/ejt.2012.7

Krapp-Schickel T. \& Sorbe J.C. 2006. Apherusa delicata n. sp., a new suprabenthic amphipod (Crustacea, Eusiroidea, Calliopiidae) from the northern Bay of Biscay, with a discussion of the genus. Organisms Diversity \& Evolution 6: 57-65. https://doi.org/10.1016/j.ode.2005.05.002

Larsen K. \& Krapp-Schickel T. 2007. Amphipoda (Crustacea: Peracarida) from chemically reduced habitats; the hydrothermal vent system of the north-east Pacific. Part II. Melitidae and Eusiridae. Journal of the Marine Biological Association of the United Kingdom 87 (5): 1207-1217.

https://doi.org/10.1017/S002531540705672X

Lowry J.K. 2006. New families and subfamilies of Amphipod Crustaceans. Zootaxa 1254: 1-28.

Lowry J.K. \& Barnard J.L. 2001. Revision of the endemic Australian genus Sancho (Amphipoda, Eusiridae). Journal of Crustacean Biology 21 (1): 231-242.

https://doi.org/10.1651/0278-0372(2001)021[0231:ROTEAG]2.0.CO;2

Lowry J.K. \& Myers A.A. 2012. New, mainly southern hemisphere, freshwater families of Amphipoda (Crustacea), together with a description of the first freshwater calliopiid, Lutriwita bradburyi gen. nov. et sp. nov. Zootaxa 3499: 27-45. https://doi.org/10.11646/zootaxa.3499.1.2

Lowry J.K. \& Myers A.A. 2013. A phylogeny and classification of the Senticaudata subord. nov. (Crustacea: Amphipoda). Zootaxa 3610 (1): 1-80. https://doi.org/10.11646/zootaxa.3610.1.1

Ren X. \& Huang L. 1991. Studies on gammaridea and caprellidea (Crustacea: Amphipoda) from the northwest waters off the Antarctic Peninsula. Studia Marina Sinica 32: 185-323. [in Chinese.]

Ringvold H. \& Tandberg A.H.S. 2014. A new deepwater species of Calliopiidae, Halirages helgae (Crustacea, Amphipoda), with a synoptic table to Halirages species from the northeast Atlantic. European Journal of Taxonomy 98: 1-13. https://doi.org/10.5852/ejt.2014.98

Verheye M.L., Martin P., Backeljau T. \& d'Udekem d'Acoz C. 2016. DNA analyses reveal abundant homoplasy in taxonomically important morphological characters of Eusiroidea (Crustacea, Amphipoda). Zoologica Scripta 45: 300-321. https://doi.org/10.1111/zsc.12153

Weisshappel J.B. 2001. Distribution and diversity of the hyperbenthic amphipod family Calliopiidae in the different seas around the Greenland-Iceland-Faeroe-Ridge. Sarsia 86: 143-151.

https://doi.org/10.1080/00364827.2001.10420469

WoRMS Editorial Board 2020. World Register of Marine Species. Available from http://www.marinespecies.org [accessed 6 Jun. 2020]. https://doi.org/10.14284/170

Manuscript received: 5 September 2019

Manuscript accepted: 18 May 2020

Published on: 29 July 2020

Topic editor: Rudy Jocqué

Desk editor: Pepe Fernández

Printed versions of all papers are also deposited in the libraries of the institutes that are members of the EJT consortium: Muséum national d'histoire naturelle, Paris, France; Meise Botanic Garden, Belgium; Royal Museum for Central Africa, Tervuren, Belgium; Royal Belgian Institute of Natural Sciences, 
Brussels, Belgium; Natural History Museum of Denmark, Copenhagen, Denmark; Naturalis Biodiversity Center, Leiden, the Netherlands; Museo Nacional de Ciencias Naturales-CSIC, Madrid, Spain; Real Jardín Botánico de Madrid CSIC, Spain; Zoological Research Museum Alexander Koenig, Bonn, Germany; National Museum, Prague, Czech Republic. 